\title{
Evaluation of Minimally Processed Apples with Application of Edible Films through Biospeckle
}

\author{
Lucas Sacramoni Peixoto, Juliana Aparecida Fracarolli and Rosa Helena Aguiar \\ Department of Pre-processing Agricultural Products, School of Agricultural Engineering, University of Campinas, Campinas, São \\ Paulo 13083875, Brazil
}

\begin{abstract}
The search for practical eating has been increasing among consumers. Thus, minimally processed (MP) foods, which are fresh, previously cut, washed, sanitized and packed products, may be covered with films so as to keep their quality, reducing the deterioration processes. This paper aimed to evaluate the quality of fresh cut apples covered and uncovered with an edible film, through conventional techniques and through biospeckle which is an alternative method of quality evaluation. That analysis was correlated to methods, such as Hunter $L^{*}, a^{*}$ and $b^{*}$ parameters. Total soluble solids (TSS), total titratable acidity (TTA), respiration rate and $\mathrm{pH}$, as well as the biospeckle optical technique, were measured through the calculation of the moment of inertia (MI). Apples were sorted into three sets: samples with sodium alginate edible film, samples with pectin edible film and control samples with no film. In optical tests, a diode laser with a wavelength of $632 \mathrm{~nm}$, a digital camcorder, a computer with image processing and statistical software were used. Results showed that both edible films (alginate and pectin) presented lower MI values, indicating the decrease of the biological activity. The conservation of the products observed through the reduction of biological activity promoted by the films keeps the apple quality for a longer period of time. The biospeckle technique can be related to the intensity of the biological activity of the vegetable tissue.
\end{abstract}

Key words: Malus domestica, biospeckle, quality, image processing, moment of inertia, sodium alginate, pectin.

\section{Introduction}

In the harvest during 2014-2015, 1,144,814 tons of apples were produced in Brazil [1], which classifies the country among the 10 biggest producers in the world. It is also highlighted the high consumer demand for the fruit.

Currently, there is a high consumer demand for fresh fruit, such as, the minimally processed (MP) ones, which are products that go through the selection, washing, sanitation, peeling, cut, centrifugation, packing, storage and commercialization processes [2]. At the end of those operations, the product must remain fresh and conserved. That process aims to add value to the product, in order to increase the competitiveness of the production sector, making alternate commercialization means possible [3].

During that processing, the MPs suffer many

Corresponding author: Juliana Aparecida Fracarolli, assistant professor, research field: post-harvest technology. mechanical injuries, which affect the tissues, causing them to present a more accentuated physiological deterioration and thus reducing the products' conservation time. Those mechanical damages induce undesirable reactions, and the product starts defending itself by increasing the respiratory rate, the production of ethylene and the activities of enzymes responsible for the darkening and softening of the tissue, development of unpleasant odors and flavors [4].

One way to conserve the MP products is through the use of edible covers, which are a thin layer of material formed on the surface of the product and involve all the surface of the product, through immersion or aspersion [5]. The film aims to reduce the migration of water, oxygen, carbonic gas and smells, since it works as semi-permeable barriers [6]. The edible films can also contain antioxidant and antimicrobial compounds, among others [7]. 
Currently, there are many methodologies to evaluate products. Some of them are expensive and slow methodologies, using microbiological, chemical materials and physical destructive methods for analysis [8]. Therefore, it would be promising to use fast and non-destructive methods to evaluate the quality of agricultural products.

The optical techniques may work as alternate methodologies to evaluate the quality of agricultural products. Among the optical techniques, it is highlighted the biospeckle. Biospeckle consists of an interference pattern which is formed when the light is dispersed on some material in activity, as is the case of vegetables [9]. The interference pattern is modified through time due to the structures responsible for the spreading in activity [10].

One of the causes of the MPs' fast deterioration is the increase of the respiratory rate, which is an indication of metabolic activity of the agricultural products [11]. According to Kader [12], the perishability of agricultural products is directly related to the respiratory rate, thus the rate may generate important information regarding the quality of the products and their useful life.

In order to obtain information on the activity of biological tissues through biospeckle, it is necessary to use image processing, being able to generate visual results like the Fujii method, and general differences or numerical results like the moment of inertia (MI) and others.

Alves et al. [10] evaluated MP fruit stored at temperatures between $0{ }^{\circ} \mathrm{C}$ and $10{ }^{\circ} \mathrm{C}$ through biospeckle and monitored the measurements through the measurement of respiratory rate, water activity and humidity.

This paper aimed to evaluate the quality of MP Gala apples subjected to the application of two edible covers-sodium alginate and pectin, through traditional methods compared to the biospeckle through the calculation of MI value.

\section{Materials and Methods}

\subsection{Apple Processing and Preparation of the Cover Forming Solutions}

Gala apples were obtained at local market, taken to the Post-Harvest Laboratory of the School of Agricultural Engineering (FEAGRI) of the University of Campinas (UNICAMP) and kept in environment at $17{ }^{\circ} \mathrm{C}$. The apples were then sanitized, sliced (eight slices per apple) and divided into three sets: samples covered with pectin, samples covered with sodium alginate and samples with no cover (control).

The alginate cover forming solution was prepared at $2 \%$ concentration (40 $\mathrm{g}$ of alginate/ $2 \mathrm{~L}$ of distilled water), heated to $70{ }^{\circ} \mathrm{C}$ under constant agitation, and then left to cool at room temperature and kept at rest for $16 \mathrm{~h}$ to eliminate air bubbles. When the solution was ready, the samples were firstly immersed in calcium lactate solution at $2 \%$ for $1 \mathrm{~min}$ to promote the gelling of the sodium alginate. They were then immersed in the alginate solution for $2 \mathrm{~min}$.

The pectin cover forming solution was also prepared at $2 \%$ (40 g of pectin/2 L of distilled water). The solution was heated to $70{ }^{\circ} \mathrm{C}$ under constant agitation, then cooled to room temperature and kept at rest for $16 \mathrm{~h}$ to eliminate air bubbles.

Both the samples immersed in alginate and the ones immersed in pectin were put at rest after the immersion so that the cover would dry. Then, the samples of the three treatments (alginate, pectin and control) were placed in plastic packages (Fig. 1).

Fig. 2 presents a flowchart of the whole process, from the reception of the apples to the conditioning of the packages.

\subsection{Conventional Analysis of Samples}

All three treatments were monitored by consolidated methodologies, such as respiratory rate, total soluble solids (TSS), total titrable acidity (TTA), $\mathrm{pH}$, color and texture. Simultaneously, the treatments were evaluated through biospeckle as comparison. 
Evaluation of Minimally Processed Apples with Application of

\section{Edible Films through Biospeckle}

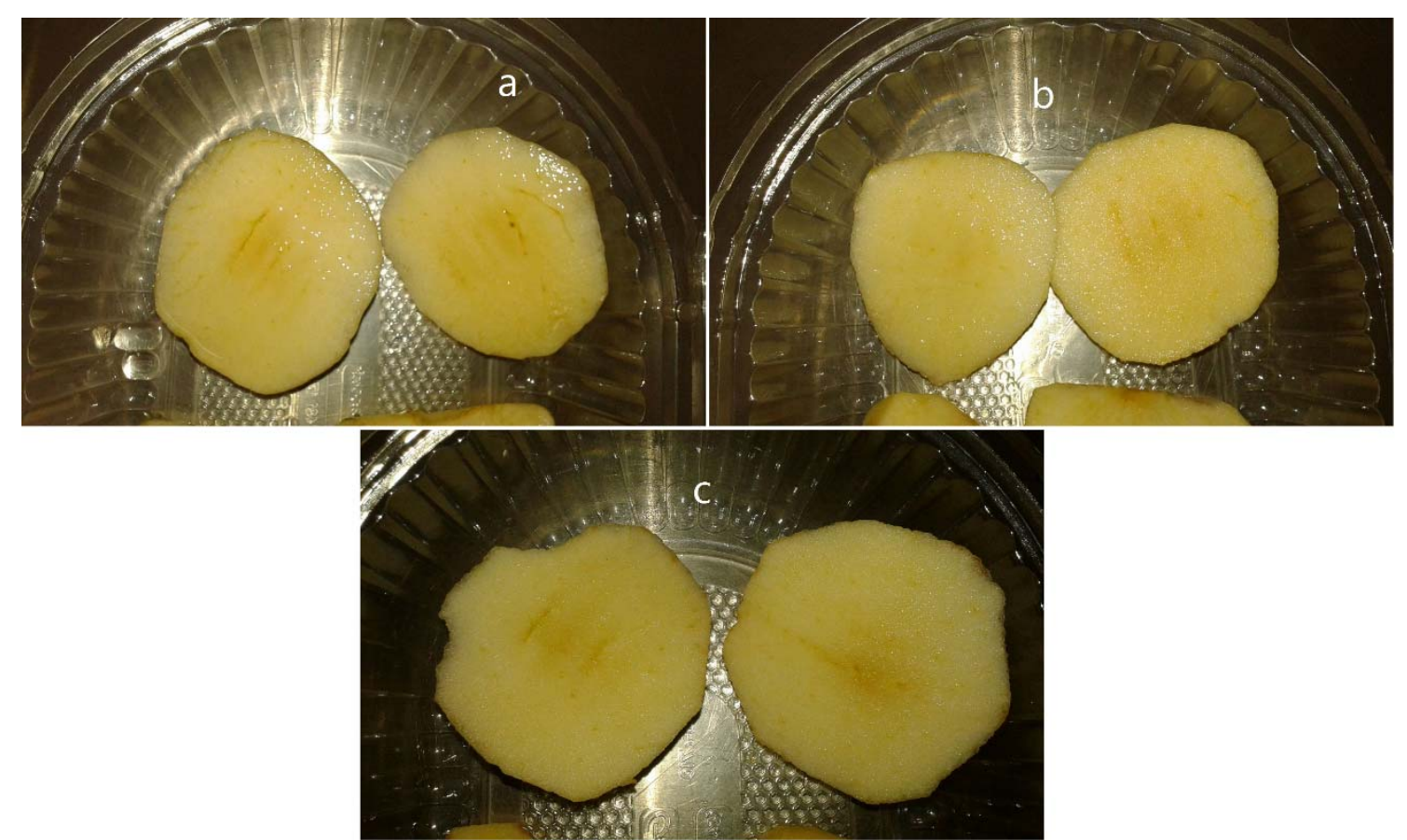

Fig. 1 Apples after the conditioning in packages and immersed in sodium alginate (a), pectin (b) and control samples (c).

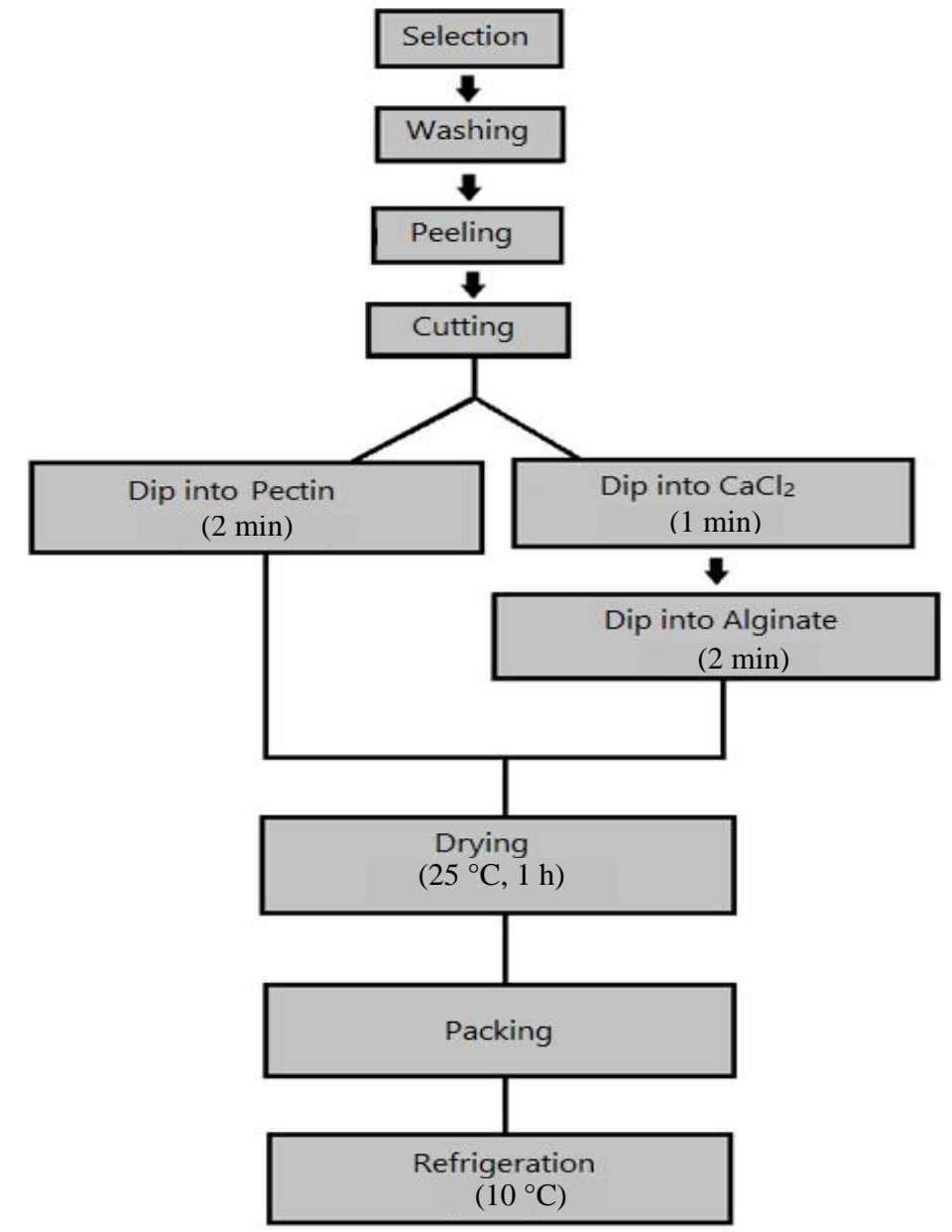

Fig. 2 Flowchart of the process of preparation of the samples and solutions which will generate the studied films. 
The respiratory rate measurements were performed in the Post-Harvest Laboratory of School of Agricultural Engineering of UNICAMP using a Pac Check 325 gas composition analyzer $\left(\mathrm{CO}_{2}\right.$ and $\left.\mathrm{O}_{2}\right)$ of the MOCON brand. The respiratory rate was calculated as Eq. (1):

$$
\begin{aligned}
& \text { Respiration rate ratio = } \\
& \frac{\mathrm{mL} \mathrm{CO} / \mathrm{kg} \cdot \mathrm{h} \text { in alginate or pectin sample }}{\mathrm{mL} \mathrm{CO} / \mathrm{kg} \cdot \mathrm{h} \text { in control sample }}
\end{aligned}
$$

TSS was determined through the volume of sodium hydroxide $(\mathrm{NaOH})$ at $0.1 \mathrm{~mol} / \mathrm{L}$ necessary to titrate 10 $\mathrm{g}$ of the crushed, diluted and homogenized sample in $90 \mathrm{~mL}$ of distilled water [13], and the results were expressed in percentage of malic acid. The crushed samples were used to determine the $\mathrm{pH}$, which was obtained with a Cole Parmer potentiometer. Three repetitions were performed for each treatment.

To evaluate the color, it was used a portable colorimeter of the mini Scan XE made of the Hunter brand. It performed the direct reading of the Hunter $L^{*}$, $a^{*}$ and $b^{*}$ parameters, where $L$ represents lightness, ranging from 0 (black) to 100 (white), $a$ and $b$ are chroma coordinates and range from -60 to 60 (- $a=$ green, $+a=$ red, $-b=$ blue and $+b=$ yellow) [14]. Two readings of the surface were performed for each sample. The evaluation was performed based on the darkening index (DI), calculated according to Eq. (2) [15]:

$$
\mathrm{DI}=\frac{100(X-0.31)}{0.172}
$$

where, $X=\frac{\left(a^{*}+1.75 L^{*}\right)}{\left(5.645 L^{*}+a^{*}-3.02 b^{*}\right)}$.

The evaluation of TSS was performed through direct reading in ABBE MARK III Reichert automatic digital refractometer, and the results were expressed in ${ }^{\circ}$ Brix. Three repetitions were performed for each treatment.

The samples were stored for $7 \mathrm{~d}$ in cold chamber at $10{ }^{\circ} \mathrm{C}$ and were evaluated every $3 \mathrm{~d}$. A completely randomized design was used with three replications in three treatments (alginate, pectin and control). The results were submitted to analysis of variance by $F$ test and the treatment means were compared by Tukey test at 5\% probability using the Sisvar 5.3 program [16].

\subsection{Analysis through Biospeckle}

In the optical trials, a diode infrared laser with a wavelength of $632 \mathrm{~nm}$ and $10 \mathrm{~mW}$ of power, a smartphone cellular telephone with a digital camcorder with determined acquisition rate, a computer with programs to process the images and for statistical treatment were used. In order to process the images, it was used the Matlab and ImageJ programs version 1.50i [17].

A completely randomized design was used with three replications in three treatments (alginate, pectin and control). The values of the dependent variables met the assumptions of ANOVA and were analyzed without transformation. The results were submitted to analysis of variance by $F$ test and the treatment means were compared by Tukey test at 5\% probability using the Sisvar 5.3 program [16].

The response variables were adopted values of MI. Fig. 3 presents the experience arrangement for the acquisition of the images to be processed for evaluation through biospeckle.

\section{Results and Discussion}

The $\mathrm{pH}$ values, TTA and TSS of the MP apples are shown in Tables 1, 2 and 3, respectively. The darkening index values are shown in Table 4 and the MI values in Table 5.

3.1 Physiological, Physicochemical and Physical Analysis through Conventional Method

In general, the MP apples' $\mathrm{pH}$ tended to decrease along the days. The apples with an alginate film presented higher values, while the control samples presented lower values. The presence of the alginate film, as well as, the pectin one, made the samples 


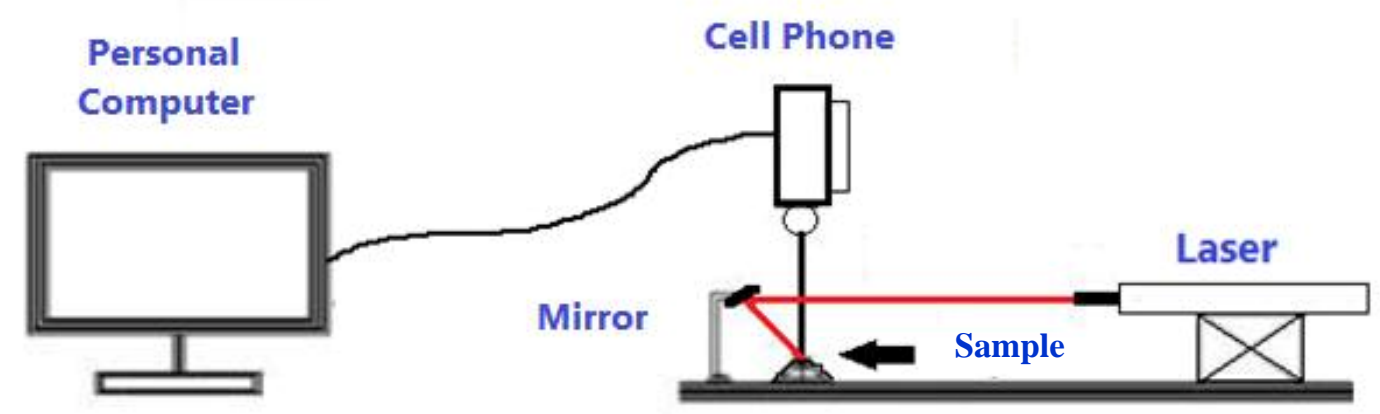

Fig. 3 Experience set up for evaluation through biospeckle.

Table 1 pH values averages for the three treatments throughout the storage.

\begin{tabular}{llll}
\hline Treatment & \multicolumn{2}{c}{$\mathrm{pH}$ values } \\
\cline { 2 - 4 } & 1 st day & 4 th day & 7 th day \\
\hline Alginate & $4.47^{\mathrm{b}}$ & $4.07^{\mathrm{b}}$ & $4.19^{\mathrm{b}}$ \\
Pectin & $4.25^{\mathrm{a}}$ & $3.87^{\mathrm{a}}$ & $3.76^{\mathrm{a}}$ \\
Control & $4.27^{\mathrm{a}}$ & $3.77^{\mathrm{a}}$ & $3.64^{\mathrm{a}}$ \\
\hline
\end{tabular}

a, b Means with different superscripts letters in the same column are significantly different $(P<0.05)$ through Tukey's test.

Table 2 Total titrable acidity values average given as malic acid equivalent (\%) for the three treatments along the storage.

\begin{tabular}{llll}
\hline \multirow{2}{*}{ Treatment } & \multicolumn{3}{c}{ Total titrable acidity (malic acid equivalent (\%)) } \\
\cline { 2 - 4 } & 1st day & 4th day & 7 th day \\
\hline Alginate & $0.2200^{\mathrm{a}}$ & $0.2194^{\mathrm{a}}$ & $0.2131^{\mathrm{a}}$ \\
Pectin & $0.2462^{\mathrm{a}}$ & $0.2760^{\mathrm{b}}$ & $0.3101^{\mathrm{b}}$ \\
Control & $0.3077^{\mathrm{b}}$ & $0.2790^{\mathrm{b}}$ & $0.2966^{\mathrm{b}}$ \\
\hline
\end{tabular}

a, b Means with different superscript letters in the same column are significantly different $(P<0.05)$ through Tukey's test.

Table 3 Total soluble solids values averages (in ${ }^{\circ}$ Brix) for the three treatments along the storage.

\begin{tabular}{llll}
\hline \multirow{2}{*}{ Treatment } & \multicolumn{2}{c}{ Total soluble solids ( ${ }^{\circ}$ Brix $)$} \\
\cline { 2 - 4 } & 1 st day & 4 th day & 7 th day \\
\hline Alginate & $12.41^{\mathrm{a}}$ & $11.61^{\mathrm{a}}$ & $11.59^{\mathrm{a}}$ \\
Pectin & $12.75^{\mathrm{a}, \mathrm{b}}$ & $11.63^{\mathrm{a}}$ & $12.51^{\mathrm{b}}$ \\
Control & $13.36^{\mathrm{b}}$ & $12.31^{\mathrm{a}}$ & $13.56^{\mathrm{c}}$ \\
\hline
\end{tabular}

${ }^{\mathrm{a}-\mathrm{c}}$ Means with different superscript letters in the same column are significantly different $(P<0.05)$ through Tukey’s test.

Table 4 Darkening index values averages for the three treatments along the storage.

\begin{tabular}{llll}
\hline \multirow{2}{*}{ Treatment } & \multicolumn{2}{c}{ Darkening index } \\
\cline { 2 - 4 } & 1 st day & 4 th day & 7 th day \\
\hline Alginate & $28.99^{\mathrm{a}}$ & $30.39^{\mathrm{a}}$ & $34.44^{\mathrm{a}}$ \\
Pectin & $34.22^{\mathrm{a}}$ & $39.99^{\mathrm{b}}$ & $37.86^{\mathrm{a}}$ \\
Control & $35.59^{\mathrm{a}}$ & $37.75^{\mathrm{b}}$ & $33.18^{\mathrm{a}}$ \\
\hline
\end{tabular}

${ }^{\mathrm{a}, \mathrm{b}}$ Means with different superscript letters in the same column are significantly different $(P<0.05)$ through Tukey's test.

present higher $\mathrm{pH}$ values compared to the control samples, and it also assured a lower $\mathrm{pH}$ variation along the storage days. The difference of $\mathrm{pH}$ values among the treatments became bigger along the storage.

The TTA of the MP apples with an alginate film had a small reduction, while the samples with pectin had an increase on acidity.

The TSS was higher for the control treatment apples and lower for the apples with an alginate film. Only the values referring to the treatment with 
alginate presented a reduction along the days.

Since the $\mathrm{pH}$, TTA and TSS content are determined with crushed samples, the film substances influenced the $\mathrm{pH}$, which differentiated the averages of the three treatments.

The MP apples with a sodium alginate film presented the lowest darkening indexes, and the apples with a pectin film were the highest. On the MP apples with sodium alginate, it was observed an increase on the darkening index along the storage, while it did not occur with the control samples and the ones with pectin, which did not present a defined behavior, increasing between days 1 and 4, and decreasing between days 4 and 7 (Fig. 4).

The values of $\mathrm{CO}_{2}$ released by the samples of the three treatments presented a respiration rate peak on the second day, which, according to Fontes et al. [18], may be a result of the stress provoked by the peeling

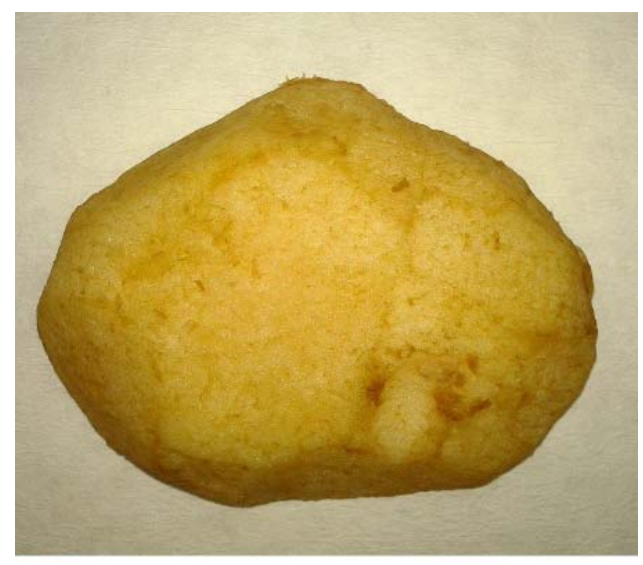

(a) Control sample and cutting of the tissue, causing cell partitioning loss, and with that, the respiration metabolism substrates get in contact with the enzyme complexes, resulting in an increment of the respiration rate. Due to respiration rate peak, the values of the second day were not used for comparison between the treatments.

Fig. 5 presents a respiration rate ratio curve, where the ordinate values are obtained based on Eq. (1). Thus, it is possible to see how much more or less those samples breathed, as compared to the control samples. Thus, the respiration rate ratio curve of the control treatment is equal to 1 . The values were normalized, having the control treatment as the reference value.

The samples treated with a pectin coating presented higher respiration than the control samples. It occurred throughout the storage period, presenting an average respiration rate ratio of 1.09, i.e., $9 \%$ higher. The samples

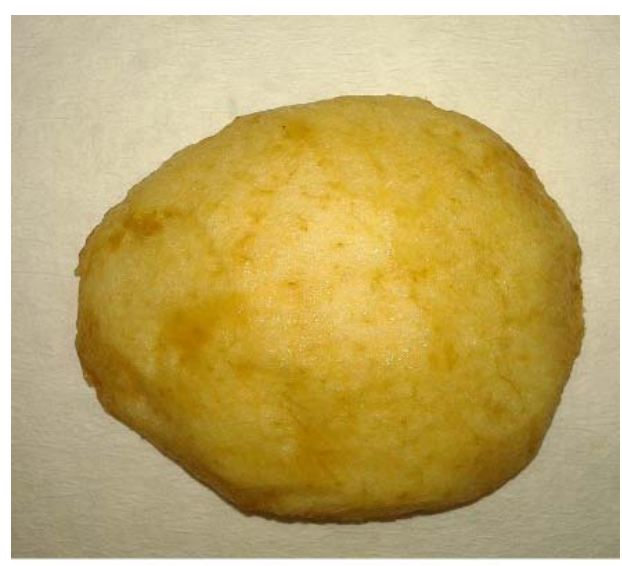

(b) Pectin film sample

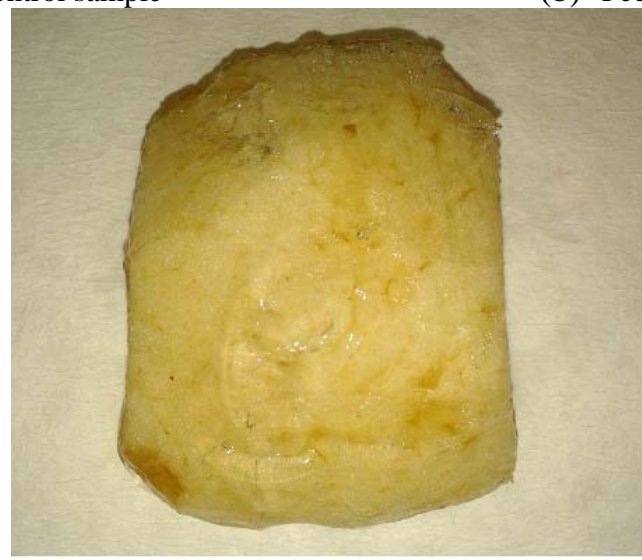

(c) Sodium alginate film sample

Fig. 4 Control sample (a), pectin film sample (b) and sodium alginate film sample (c) on the 7th day of storage. 


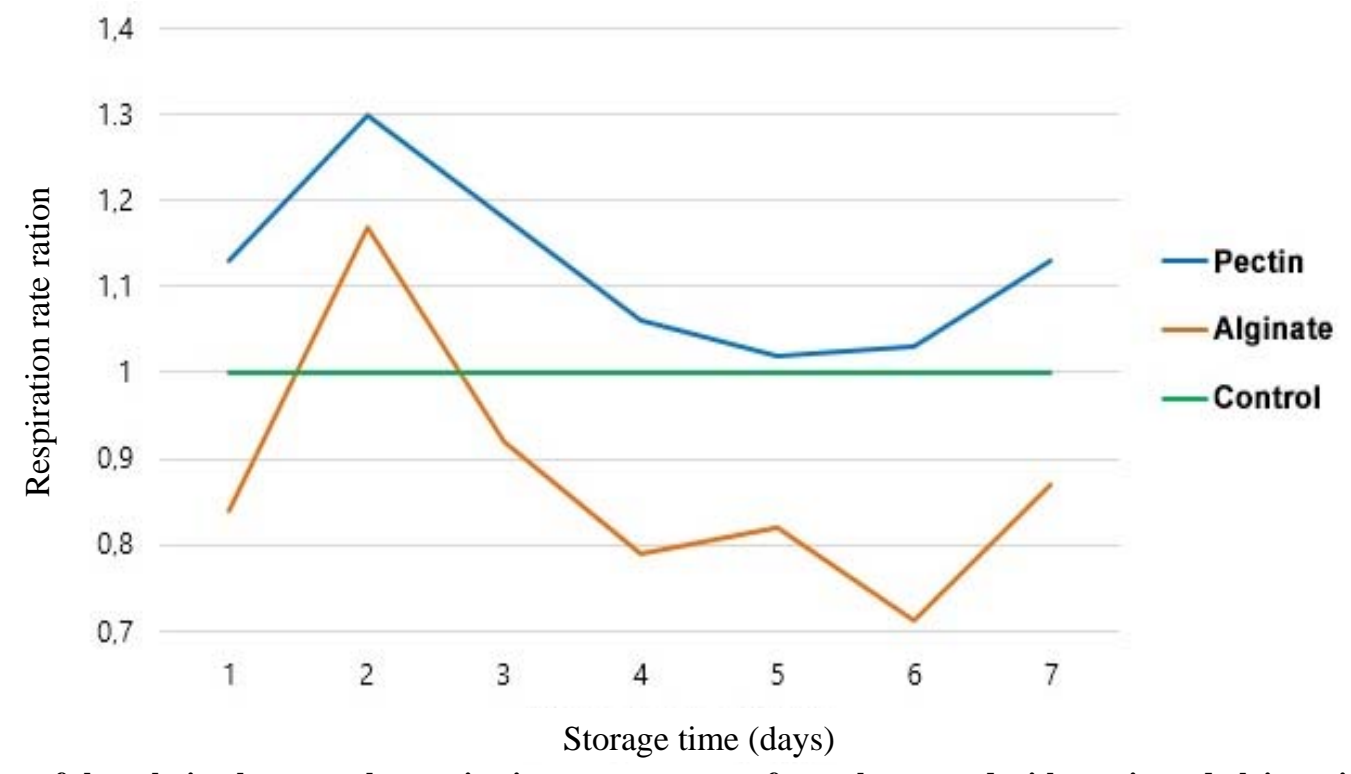

Fig. 5 Curve of the relation between the respiration rate averages of samples treated with pectin and alginate in relation to the average values of the respiration rate of the control samples.

Table 5 Moment of inertia values averages for the three treatments along the storage.

\begin{tabular}{llll}
\hline \multirow{2}{*}{ Treatment } & \multicolumn{3}{c}{ Moment of inertia values } \\
\cline { 2 - 4 } & 1 st day & 4 th day & 7 th day \\
\hline Alginate & $1.17^{\mathrm{a}}$ & $2.22^{\mathrm{a}}$ & $1.31^{\mathrm{a}}$ \\
Pectin & $1.54^{\mathrm{b}}$ & $1.71^{\mathrm{a}}$ & $1.56^{\mathrm{a}}$ \\
Control & $1.76^{\mathrm{c}}$ & $2.14^{\mathrm{a}, \mathrm{b}}$ & $1.86^{\mathrm{b}}$ \\
\hline
\end{tabular}

${ }^{\mathrm{a}-\mathrm{c}}$ Means with different superscript letters in the same column are significantly different $(P<0.05)$ through Tukey's test.

treated with an alginate coating were efficient on the respiration control, presenting a respiration ratio of 0.83 , i.e., $17 \%$ lower than the respiration rate of the control samples.

The sodium alginate coating treatment was more efficient than the pectin coating treatment on the respiration rate control of the MP apples. The efficiency of sodium alginate coating concerning the gas exchange control is possibly due to its nature, thickness, or continuous surface formation [18].

According to Fontes et al. [18], MP apples with a sodium alginate coating film were more efficient, compared to the control treatment, on the reduction of the respiratory rate, presenting an average of $1.48 \mathrm{~mL}$ $\mathrm{CO}_{2} / \mathrm{kg} \cdot \mathrm{h}$.

\subsection{Analysis through Biospeckle}

The results for the samples evaluated through biospeckle are in Table 5.

The MP apples with the alginate and pectin films presented lower MI values compared to the control samples. The three treatments presented an increase between day 1 and day 4, and a decrease on day 7 .

The decrease of the MP apples' MI with alginate and pectin films may be related to the reduction which those films cause on the samples' respiratory rate.

In a study with potato tubers fresh cutted, the authors concluded that the MI method with wavelet transform was able to evaluate several physiological activities of fruits and vegetables in a nondestructive way, and also that the biospeckle can be used to study different effects of chemicals on metabolic activity of fruits and vegetables [19].

\section{Conclusions}

The MP apples covered with an alginate film 
presented lower MI values, darkening index, ${ }^{\circ}$ Brix and acidity. While the MP apples covered with alginate presented higher $\mathrm{pH}$ values, and the control samples the lowest values. Both edible films (alginate and pectin) presented lower MI values, showing that those films decreased the biological activity of the tissues, that is, the biospeckle technique can be related to the intensity of the biological activity of the vegetable tissue as well as the respiratory rate. And the biospeckle may be an alternate technology to evaluate biological tissue. The conservation of the products observed through the reduction of biological activity promoted by the films keeps the apple quality for a longer period of time, which is an advantage for MP products, which degrade faster compared to whole fruit.

\section{Acknowledgments}

The authors thank National Counsel of Technological and Scientific Development (CNPq) and Scholarship Social Support (BAS) for granting the scholarship and opportunity. The authors also thank Rosa Helena, Rivia Amaral and Gisela Maiara for the assistance, and FMC Health and Nutrition by sodium alginate donation.

\section{References}

[1] Kist, B. B. 2016. "Brazilian Apple Yearbook 2016." Santa Cruz do Sul. Accessed March 11, 2016. http://www.grupogaz.com.br/tratadas/eo_edicao/76/2016/ 06/20160613_4ffcddd7a/flip/\#20/z.

[2] Moretti, C. L. 1999. "Minimal Processing of Vegetables: A Viable Alternative for Reducing Postharvest Losses and Adding Value to Brazilian Agribusiness.” Brazilian Horticulture 17 (1): 1. (in Portuguese)

[3] Chitarra, M. I. F. 1998. Minimal Processing of Fruits and Vegetables. Viçosa: Universidade Federal de Viçosa (UFV). (in Portuguese)

[4] Baldwin, E. A., Nisperos-Carriedo, M. O., and Baker, R. A. 1995. "Use of Edible Coatings to Preserve Quality of Lightly (and Slightly) Processed Products.” Crit. Rev. Food Sci. Nutr. 35 (6): 509-24.

[5] Kester, J. J., and Fennema, O. R. 1986. "Edible Films and Coatings: A Review.” Food Technol. 40 (12): 47-59.
[6] Krochta, J. M., and Mulder-Johnston, C. 1997. "Edible and Biodegradable Polymer Films: Challenges and Opportunities.” Food Technol. 51 (2): 61-74.

[7] Maia, L. H., Porte, A., and De Souza, V. F. 2000. "Edible Films: General Aspects, Barrier Properties for Moisture and Oxygen.” Bol. Cent. Pesqui. Process. Aliment. 18 (1): 105-28. (in Portuguese)

[8] Corbo, M. R., Del Nobile, M. A., and Sinigaglia, M. 2006. "A Novel Approach for Calculating Shelf Life of Minimally Processed Vegetables.” Int. J. Food Microbiol. 106 (1): 69-73.

[9] Dainty, J. C., ed. 1984. Laser Speckle and Related Phenomena, 2nd ed.. Berlin: Springer-Verlag.

[10] Alves, J. A., Braga, R. A., and De Barros Vilas Boas, E. V. 2013. "Identification of Respiration Rate and Water Activity Change in Fresh-Cut Carrots Using Biospeckle Laser and Frequency Approach.” Postharvest Biol. Technol. 86: 381-6.

[11] Wills, R. B. H., ed. 2007. Postharvest: An Introduction to the Physiology and Handling of Fruit, Vegetables and Ornamentals, 5th ed.. Sydney, Australia: University of New South Wales Press.

[12] Kader, A. A., ed. 2002. Postharvest Technology of Horticultural Crops, 3rd ed.. Oakland, Calif: University of California.

[13] Carvalho, C. R. L., Mantovani, D. M. B., Carvalho, P. R. N., and Moraes, R. M. M. 1990. Chemical Analysis of Food. Campinas: ITAL. (in Portuguese)

[14] Bible, B. B., and Singha, S. 1993. "Canopy Position Influences CIELAB Coordinates of Peach Color." HortScience 28 (10): 992-3.

[15] Palou, E., Lopez-Malo, A., Barbosa-Canovas, G. V., Welti-Chanes, J., and Swanson, B. G. 1999. "Polyphenoloxidase Activity and Color of Blanched and High Hydrostatic Pressure Treated Banana Puree.” J. Food Sci. 64 (1): 42-5.

[16] Ferreira, D. F. 2011. "Sisvar: A Computer Statistical Analysis System.” Ciência e Agrotecnologia 35 (6): 1039-42.

[17] Schneider, C. A., Rasband, W. S., and Eliceiri, K. W. 2012. "NIH Image to ImageJ: 25 Years of Image Analysis.” Nat. Methods 9: 671-5.

[18] Fontes, L. C. B., Sarmento, S. B. S., Spoto, M. H. F., and Dos Santos Dias, C. T. 2008. "Preservation of Minimally Processed Apple with the Use of Edible Films.” Ciênc. Tecnol. Aliment. 28 (4): 872-80. (in Portuguese)

[19] Minz, P. D., Ansari, M. Z., and Nirala, A. K. 2015. "Effect of Antibrowning Agents on Fresh-Cut Potato Tubers Using Frequency Filtering of Biospckle Images.” Laser Phys. 25 (5): 055601. 